\title{
ON THE ACTION WHICH IT IS DESIRABLE SHOULD BE TAKEN TO CORRECT THE ERRONEOUS ENTRY RELATING TO THE NAME "ASTACUS" PALLAS, 1772 (CLASS CRUSTACEA, ORDER DECAPODA) MADE IN THE "OFFICIAL LIST OF GENERIC NAMES IN ZOOLOGY" BY "OPINION" 104
}

\author{
By L. B. HOLTHUIS \\ (Rijksmuseum van Natuurlijke Historie, Leiden, The Netherlands)
}

(Commission's reference Z.N.(S.)544)

(Extract from a letter dated 8th June 1951)

Thank you so much for your letter Z.N.(S.)544 of 6th June concerning Astacus Pallas, 1772 (Spicil. Zool. 9:81) type species: Astacus dauuricus Pallas, 1772 (Spicil. Zool. 9 : 81) monotypic.

As to your questions concerning Pallas's species I can give you the following information. Astacus dauuricus Pallas is a well recognisable species and the trivial name dauuricus, being the oldest name available for the species, at present still is in common usage. The species, however, is no longer retained in the genus Astacus, but is placed in a separate genus Cambaroides Faxon (1884, Proc. Amer. Acad. Arts Sci. 20 : 149) type: Astacus japonicus De Haan (1841, Fauna japon. Crust. (5) : 164, pl. 35 fig. 9) by subsequent designation Faxon (1898, Proc. U.S. nat. Mus. $20: 665$ ). Faxon (1884) described Cambaroides as a subgenus of Astacus, but Stebbing (1893, Hist. Crust. : 208) raised it to the rank of a genus, in which he is followed by all modern authors.

To me it seems highly desirable that the Commission should undertake steps to prevent the confusion, which undoubtedly will be the result if Astacus dauricus Pallas is chosen to be the type species of the genus Astacus. From the two alternatives mentioned in your letter therefore I certainly would choose the second, and let the Commission use its plenary powers to make Cancer astacus Linnaeus (1758, Syst. Nat. (ed. 10) $1: 631$ ) the type species of the genus Astacus.

I would suggest therefore that the Commission should not place Astacus Pallas, 1772, on the Official List, but Astacus Fabricius, 1775 (Syst. Ent. : 413) type species : Astacus fluviatilis Fabricius (1775, Syst. Ent. : 413) (=Cancer astacus Linnaeus, 1758, Syst. Nat. (ed. 10) $1: 631$ ) type by subsequent selection (Latreille, 1810, Consid. gén. Crust. Arachn. Ins. : 422). Nearly all authors using the generic name Astacus attribute it to Fabricius, 1775. 

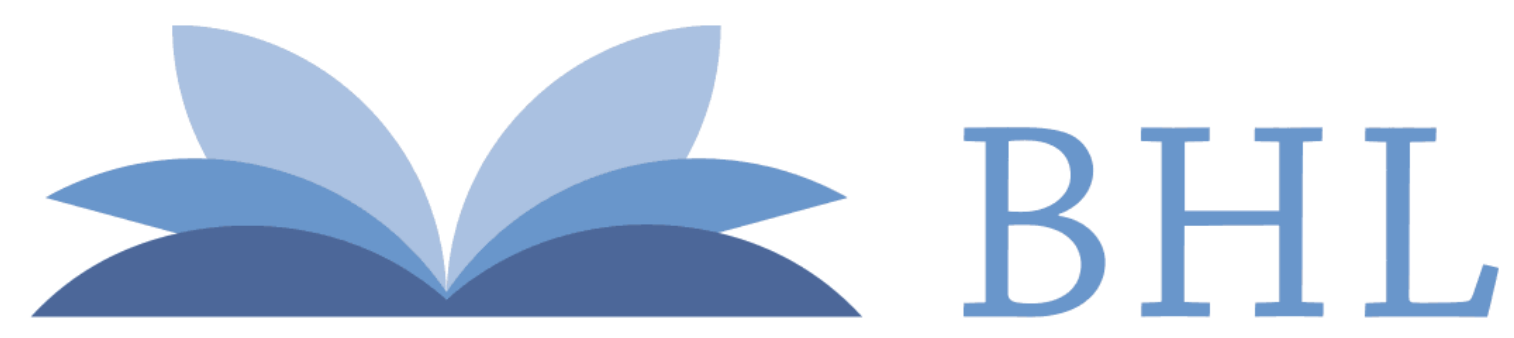

\section{Biodiversity Heritage Library}

Holthuis, L. B. 1952. "On the action which it is desirable should be taken to correct the erroneous entry relating to the Name "Astacus" Pallas, 1772 (class Crustacea, order Decapoda) made in the "Official List of generic names in Zoology" by "Opinion" 104." The Bulletin of zoological nomenclature 9, 118-118. https://doi.org/10.5962/bhl.part.10249.

View This Item Online: https://www.biodiversitylibrary.org/item/44291

DOI: https://doi.org/10.5962/bhl.part.10249

Permalink: https://www.biodiversitylibrary.org/partpdf/10249

\section{Holding Institution}

Natural History Museum Library, London

\section{Sponsored by}

Natural History Museum Library, London

\section{Copyright \& Reuse}

Copyright Status: In copyright. Digitized with the permission of the rights holder.

License: http://creativecommons.org/licenses/by-nc-sa/3.0/

Rights: https://biodiversitylibrary.org/permissions

This document was created from content at the Biodiversity Heritage Library, the world's largest open access digital library for biodiversity literature and archives. Visit BHL at https://www.biodiversitylibrary.org. 